\title{
Biclonal Gammopathy
}

National Cancer Institute

\section{Source}

National Cancer Institute. Biclonal Gammopathy. NCI Thesaurus. Code C74936.

A primary disturbance in immunog lobulin synthesis characterized by the presence of two distinct monoclonal immunoglobulins in the serum or urine. 